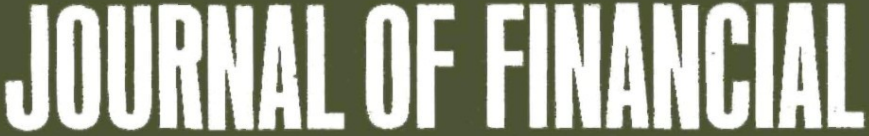

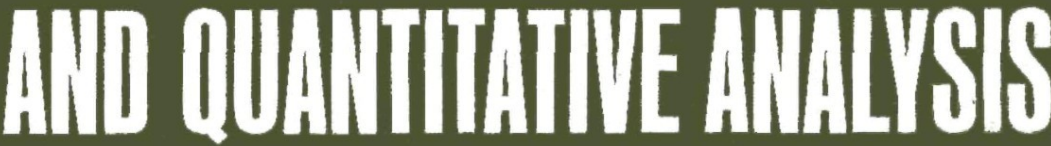

\section{June 1980}

FRANK MILNE AND CLIFFORD SMITH, JR. Caphat Asees Pricing with Proportional Transection Costs

DAVID F. LARCKER, LAWRENCE A. GORDON, AND GEORGE E. PINCHES Testing for Market Elliciency: A Comperison of the Cumulative Average Reeldual Methodology and Intervention Analysis

MOSHE BEN-HORIM AND HAIM LEVY

Total Alisk, Diversellieblo Flisk and Non-Diversiliablo Flisk: A Pedepogic Nots

ROGER P. BEY AND GEORGE E. PINCHES

Additional Evidence of Heteroschedaeticity in the Market Model

ANTHONY SAUNDERS, CHARLES WARD, AND RICHARD WOODWARD

Stochastic Dominance and the Performances of U.K. Unill Trusts

GABRIEL A. HAWAWINI AND ASHOK VORA

Evidence of Intertemporal Systemetic Fileks in the Delly. Price Movernents of NYSE and AMEX Common Stocks

\author{
M. H. VAN LANDINGHAM \\ The Day Treder. Soms Addillonel Evidence
}

GEORGE M. FRANKFURTER AND HERBERT E. PHILLIPS

Portholio Solection: An Anelybic Approech for Selecting Securtities from a Large Universe

WAYNE Y. LEE AND ANDREW J. SENCHAK, JR.

On the Sociel Optimatiby of the Valus Maximization Criterion

\section{WILLAM BERANEK \\ The AB Procesture and Cepplat Buctoeting}

JACK E. GAUMNITZ AND DOUGLAS R. EMERY

Aseet Growth, Abendorment Value and the Replecement Decision of Liko-tor-Like Capital Asests

RICHARD H. BERNHARD AND. CARL J. NORSTREM

A Further Note on Unrecovered Investment, Uniqueness of the Internel Rate, and the Question of Project Acceptability

\section{S. PYUN}

A Notes on Capital Aoset Pricing Model under Uncertain inmation

ERIC H. SORENSEN

An Analysis of the Relationship between Underwither Spread and the Pricing of Municipel Bonds

H. RUSSELL FOCLER AMD S. GANAPATHY

Comment on: "A Quentititive Vied Curve Model for Estimeting the Term Structure of interest Rates"

JEROME B. BAESEL AND NAHUM BIGER

The Alocation of Plisk: Some Inplicallons of Fibed versus index-Linked Mortosoes

\section{LUCILLE S. MAYNE}

Bank Dividend Pollicy and Holding Compeny Alimetion

Proliminary Progrem of the 15th Amuel Conterences of the Weetern Finence Association 
JOURNAL OF FINANCIAI AND QUANTITATIVE ANALYSIS

A JOINT PUBLICATION

OF THE

\author{
GRADUATE SCHOOL OF BUSINESS ADMINISTRATION \\ UNIVERSITY OF WASHINGTON \\ AND THE
}

WESTERN FINANCE ASSOCIATION

POLICY ADVISORY COMMITTEE

Guilford C. Babcock

Charles A. D'Ambrosio

Donald E. Farrar

Alan Kraus

William F. Sharpe

Seha M. Tinic

EDITORIAL STAFF

Robert C. Higgins, Managing Editor

Marty Auvil, Editorial Associate

University of Washington

ASSOCIATE EDITORS

\author{
Richard H. Bernhard, North Carolina State Barr Rosenberg, Berkeley \\ Gerald O. Bierwag, Oregon \\ Gary G. Schlarbaum, Purdue \\ Andrew H. Chen, Ohio state \\ Clifford W. Smith, Jr., Rochester \\ Peter A. Frost, Washington \\ Bruno H. Solnik, CESA, \\ Robert S. Hamada, Chicago \\ Jouy-en-Josas, France \\ Frank C. Jen, SuNY, Buffalo \\ Bernell K. Stone, Georgia Institute \\ George Kaufman, Oregon \\ of Technology \\ Michael A. Klein, Indiana \\ James Van Horne, Stanford \\ Cheng-few Lee, Illinois \\ John G. McDonald, Stanford \\ David A. Walker, Federal Deposit \\ Insurance Corporation \\ Richard Pettit, Houston \\ Richard R. West, Dartmouth \\ George E. Pinches, Kansas \\ Robert L. Winkler, Indiana
}


Donald E. Farrar, President

Charles A. D'Ambrosio, President-Elect

James $C$. Van Horne, Vice President

D. Stuart Bancroft, Secretary-Treasurer Guilford C. Babcock, Past President

Robert C. Higgins, Editor

Thomas E. Stitzel

George N. Engler

Alan Kraus

William F. Sharpe

\author{
University of Utah \\ University of washington \\ Stanford University \\ Pacific Iutheran University \\ University of Southern California \\ University of Washington \\ Boise State University \\ California state University \\ University of British Columbia \\ Stanford University
}

INSTITUTIONAL MEMBERS
Loyola Marymount University College of Business Administration University of Southern California Graduate School of Business Administration University of Utah Department of Finance First security corporation Salt Lake City, Utah

CORPORATE SPONSORS

Security Pacific National Bank

Wells Fargo Bank

Transamerica Corporation

Bank of America

Huntsman Chemical \& Oil Corporation

Mattel, Inc.

Gifford Fong Associates

\begin{abstract}
Los Angeles, California
San Francisco, California

San Francisco, California

San Francisco, California

Salt Lake City, Utah

Hawthorne, California

Santa Monica, California
\end{abstract}

Copyright 1980 by the Graduate School of Business Administration, University of Washington 
The Journal of Financial and Quantitative Analysis is published by the Graduate School of Business Administration, University of Washington, Seattle, Washington, 98195, in conjunction with the Western Finance Association. Regular issues are published in March, June, september, and December, and a Proceedings Issue is published in November. Second-class postage is paid at Seattle, Washington.

The Proceedings Issue contains selected papers, abstracts of papers, discussants' comments, and the proceedings of the Western Finance Association meetings. From time to time a special issue, devoted to one topic of interest to the membership, is published.

The views and opinions expressed are those of the authors and do not necessarily reflect those of the Graduate School of Business Administration of the University of Washington nor of the Western Finance Association.

For individuals, the annual subscription rate to the JFQA is $\$ 17.50$ (threeyear rate, $\$ 47.50)$; for firms or libraries, the annual rate is $\$ 25.00$ (threeyear rate $\$ 70)$. Annual subscription rates for individuals and libraries outside the United States (except Canada) are $\$ 18.50$ for individuals (three-year rate $\$ 50.50$ ), and $\$ 26.00$ for libraries and firms (three-year rate, $\$ 73$ ). Single copies are $\$ 5.00$. The fiscal year of the Journal of Financial and ouantitative Analysis begins on January 1 .

Manuscripts and $\$ 25$ submission fee per manuscript ( $\$ 15$ for W.F.A. members) as well as editorial correspondence, should be sent to the Managing Editor. Correspondence relating to advertising, subscriptions, and billing should be addressed: Subscription Manager, JFQA, University of Washington, DJ-10, Seattle, WA 98195.

Correspondence pertaining to the Western Finance Association should be sent to Mr. D. Stuart Bancroft, Secretary-Treasurer, School of Business Administration, Pacific Lutheran University, Tacoma, WA 98447. 
University of Washington, Seattle, Washington

Volume $X V$, No. 2, June 1980

Capital Asset Pricing with Proportional

Transaction Costs . . . . . . . . . . . . . . . . . . . . . . .

Frank Milne and Clifford Smith, Jr.

Testing for Market Efficiency: A Comparison

of the Cumulative Average Residual Methodology

and Intervention Analysis . . . . . . . . .

George $E$. Pinches

Total Risk, Diversifiable Risk and Non-Diversifiable

Risk: A Pedagogic Note . . . . . . . . . . . . . . . . . . . . . . .

Moshe Ben-Horim and Haim Levy

Additional Evidence of Heteroschedasticity in

the Market Model . . . . . . . . . . . . . . . . . . . . . . . . . . .

Roger $P$. Bey and George E. Pinches

Stochastic Dominance and the Performance of

U.K. Unit Trusts . . . . . . . . . . . . . . . . . . . . . . . . .

Anthony Saunders, Charles Ward, and

Richard Woodward

Evidence of Intertemporal Systematic Risks in the

Daily Price Movements of NYSE and AMEX Common Stocks . . . . . . . . .

Gabriel A. Hawawini and Ashok Vora

The Day Trader: Some Additional Evidence . . . . . . . . . . . . . .

M. H. Van Landingham

Portfolio Selection: An Analytic Approach for

Selecting Securities from a Large Universe . . . . . . . . . . . . . . George M. Frankfurter and Herbert E. Phillips

On the Social Optimality of the Value Maximization

Criterion................................... Wayne $Y$. Lee and Andrew J. Senchak, Jr.

The AB Procedure and Capital Budgeting . . . . . . . . . . . . . . William Beranek

Asset Growth, Abandonment Value and the Replacement Decision of Like-for-Like Capital Assets . . . . . . . . . . . . . . . Jack E. Gaumnitz and Douglas $R$. Emery

A Further Note on Unrecovered Investment, Uniqueness of the Internal Rate, and the Question of Project Acceptability . . . . . . . . . . . . . . . . . . . . . . . .

Richard H. Bernhard and Carl J. Norstrom 
A Note on Capital Asset Pricing Model under

Uncertain Inflation . . . . . . . . . . . . . . . . . . . .

C. S. Pyun

An Analysis of the Relationship between Underwriter

Spread and the Pricing of Municipal Bonds . . . . . . . . . . . . . . Eric $H$. Sorensen

Comment on: "A Quantitative Yield Curve Model for

Estimating the Term Structure of Interest Rates" . . . . . . . . . . H. Russell Fogler and S. Ganapathy

The Allocation of Risk: Some Implications of Fixed

versus Index-Linked Mortgages . . . . . . . . . . . . . . . . . . . Jerome B. Baesel and Nahum Biger

Bank Dividend Policy and Holding Company Affiliation . . . . . . . 469 Lucille s. Mayne

Announcements . . . . . . . . . . . . . . . . . . . .

Preliminary Program of the 15th Annual Conference

of the Western Finance Association . . . . . . . . . . . . . . . . 